\title{
Article
}

\section{Unsettling Appearances: Diane Arbus, Erving Goffman and the Sociological}

\section{Eye}

\begin{abstract}
Both the photographer Diane Arbus and sociologist Erving Goffman were fascinated by the way we present ourselves to others and this paper sets out how each understood the drama of human interaction. It begins by exploring how their work parallels some developments in the sociology of deviance, and notes how Goffman was one of the earliest critics of this field, before briefly sketching out Arbus's controversial career and then turning to a more detailed look at three of her images. It concentrates on how the gap between intention and effect, or what Goffman terms the difference between the impressions we 'give' and those we actually 'give off', are at the core of her work and this sociological insight animates her compositions. The paper then describes how their work unsettles 'normal appearances' and provides rich resources for understanding human conduct.
\end{abstract}

\section{Keywords}

Deviance, family, photography, representation, ritual

\section{Author}

Professor Eamonn Carrabine, Department of Sociology, University of Essex, Colchester, CO4 3SQ, UK.

\section{Email: eamonn@essex.ac.uk}

Just under two decades ago it could be claimed that "visual representations. . . have been largely ignored in the social sciences," which is indicative of a "deep mistrust" of images (Holliday, 2000:503-4) in disciplines like anthropology, economics, geography and sociology, where the uses of visual material in social research have long been marginalised. Yet since then there has been a striking proliferation of diverse research methods across the social sciences, and while it is often argued that this growth is due to the increasing prominence of visual images in social life and cultural practice, it is a relationship that has yet to be fully interrogated (Rose, 
2014). The visual mode of perception has played a significant role in the social life of all human societies, but the modern world is one saturated with images to an unprecedented degree. Writing within the social sciences, the implications of this phenomenon was initially identified by Georg Simmel (1908/1921:358) when he claimed that of our five senses, the "eye has a uniquely sociological function." Simmel then describes some of the consequences of dwelling in a seen world, which include how a mutual glance can convey diverse forms of recognition: intimacy, embarrassment, shame, acknowledgement, understanding and so forth; how the intentions and moods of others can be visually read from facial expressions and bodily dispositions; how the role of visual impression increases in large-scale modern cities. These insights have been developed in a range of ways over the last century, but his crucial point about the profound significance of the visual in social life and the forms of symbolic interaction that flow through our senses is one that will be pursued here.

The way we present ourselves to others was at the core of Erving Goffman's sociology and in this paper I situate his writing in relation to the photography of Diane Arbus, in order to deepen our understanding of their respective projects. It strikes me that Arbus, whose interest in situations where the normal and abnormal meet, has some important parallels with the sociology of deviance as it was developing in the sixties. Indeed, her frequent incursions into various subcultures (nudist camps, circus side-shows, affluent ghettoes, cross-dressers, rockers, sex workers and the intellectually disabled) are seen by some as evidence of a brave and compassionate visionary. Her critics condemned her for being an exploitative narcissist, and accused her of slumming it in places she did not belong in order to generate 
disturbing portraits that took advantage of the vulnerability of her subjects. Yet, similar kind of tensions also arise in the sociology of deviance, which too has been accused of a voyeuristic fascination with "nuts, sluts and preverts" (Liazos, 1972) or more recently the "exotic, erotic and neurotic" (Adler and Adler, 2003:79). Although there is some force to these objections, what they miss is any kind of understanding of the pain and shame associated with being considered less than human.

It is often by studying life on the margins that we learn about the contours of normality. This point was central to such thinkers as Durkheim and Freud, who in different ways, insisted that those who break social laws and taboos perform important roles in society. It has been said that her approach to the "peculiar and the seemingly unfamiliar has much in common with the Freudian idea of the uncanny" (Goodwin, 2009:170). There is a sense in which she is attracted to the "forbidden" in an effort to "scrutinize the perverse, the alienated, the extreme" (Bosworth, 1984:13) and see how the boundaries of normality might be reinforced by those who seem to flaunt the social order. Arbus's work is troubling for many because her images often upset the conventional boundaries of portraiture and documentary, but in doing so she explicitly mines the terrain of social identity, from which visual social science has much yet to learn. The argument developed in this paper takes a cue from Ferrell's (2017:50) efforts to develop an "alternative historical interpretation" of the relationships between "sociological ethnography and documentary photography" by focusing on two leading representatives of both traditions.

Like Arbus, Goffman highlighted the various roles people perform in social life and through his detailed attention to the routine, seemingly trivial terrain of everyday 
interaction he revealed the rich, dynamic drama of such encounters. She was certainly aware of his work, and had in her library two of Goffman's most influential books, Asylums (1961) and Stigma (1963b), that examined the situations of those seen as different, disadvantaged or disfigured in some way. The question that then immediately arises is why has so little of substance been written exploring the relationships between Arbus and Goffman? The answer lies in the tendency to situate Arbus somewhat narrowly in the history of photography and Goffman as an inimitable sociologist of interaction. Where the two have been discussed, as in Nigel Warburton's (1992) brief piece on them, it is in relation to Goffman's (1959) earlier book The Presentation of Self in Everyday Life and the different "faces" we deploy in the company of others. For instance, it has been noted how Arbus described her childhood and the family's aspirations in a 1969 interview in the following terms: "It was a front. My father was a frontal person. A front had to be maintained" (in Goodwin, 2009:159), which the author quickly ties to Goffman's use of "front" in that earlier book, to insist that both accept the inevitability of artifice in the world of social encounters.

It is worth recalling that the concept of deviance, from Durkheim onwards, was always meant to be a broader notion than criminal behaviour, while also being less insulting to individuals and groups who departed significantly from social norms. In Stigma, Goffman (1963b) examined how people managed "spoiled identity" and exposed the very inappropriateness of the term deviance to describe physical handicap, ethnic grouping and numerous forms of social disaffiliation. As such the key quality is difference, and how this difference is bound up with cultural conflicts, social judgements and political processes. Indeed, the sociology of deviance later 
came under sustained attack for its internal contradictions and inability to confront larger questions of power, control and ideology (the reasons for this are explored in Carrabine, 2017). One of the lasting legacies of Goffman is his insistence that difference is not deviance, and he was deeply suspicious of the entire field, while attentive to the encounters between the "normals," the "discredited" and the "discreditable" in his account of Stigma (1963b).

By exploring some parallels between Arbus and Goffman I want to suggest that they not only share an interest in how the odd and unusual can shed light on the routine and ordinary, but that their close attention to the drama of human interaction reminds us "that the world is not united by a smooth surface, but by a complex network of frictions" (Hackett, 2016:14). These words were recently written to introduce a book and exhibition of image-makers, which included Arbus, but they could equally apply to Goffman's sociology. His work captures how perceptions of social worth regulate human conduct, emphasising that we all move between normal and troubled worlds, and each of us falls short some of the time, such that embarrassment (and the anxious expectation of it) haunts every social interaction. Much of his thinking sought to explain why our daily interactions do not descend into a horrific ordeal, but follow certain paths that involve us in a dynamic "mix of cynicism, ritual and trust" (Manning, 1992:72). Those who experience stigma and mental illness struggle, for very different reasons, with sustaining the mundane predictability of everyday life and his writing from the beginning offers a deep understanding of the plight of "faulty persons," describing in some detail those "who bring difficulty to many of the interactions in which they participate'”(Goffman, 1953:260). Likewise, Arbus is renowned for her disturbing portraits of odd, vulnerable, and marginal people living 
on the edge of society, but she also photographed the supposedly normal, often exposing the cracks in their public masks and was acutely aware of the awkward "gap between intention and effect" (Arbus, 1972:2) across all of her work.

As the social sciences become more visually literate and have begun to treat the world of representation as a source of analytical data it is vital that we incorporate insights from social theory in our efforts to take visual representation more seriously, observe closely and interpret the symbolic significance of their content. Both Arbus and Goffman, through their different practices, explicitly question the terms of social identity in an image-saturated world. They remind us that 'posed pictures' can 'turn out to be more substantial than one might have thought, being for students of a community's ritual idiom something like what a written text is for students of its spoken language' (Goffman, 1976:27). In other words, both candid and contrived photographs can offer insights into the 'structure of a society' and can 'lead to a social scientific understanding of the world that would not otherwise have been possible' (Chaplin, 1994:215).

\section{Situating Arbus}

Any discussion of Arbus soon runs into the cliché of her as the "Sylvia Plath of photography," leading a dark and mysterious life, that ended with her suicide in 1971 at the age of only forty-eight. There is no doubt that her astonishing compositions are often read through a mythologized biography, but this ignores the complexity of her

work and the bold ambitions she had for it. She was awarded Guggenheim fellowships in 1963 and 1966 for her project on 'American Rites, Manners and Customs', travelling across the country, photographing the people, places, and 
events she described as "the considerable ceremonies of our present...These are our symptoms and our monuments," she wrote in her grant application, explaining: "I want simply to save them, for what is ceremonious and curious and commonplace will be legendary" (in Arbus et al, 2003: 41) ${ }^{1}$. It was a selected group of these photographs that were displayed in The Museum of Modern Art's 1967 landmark exhibition in New York, entitled New Documents, which initially drew critical and popular attention to her work. But it is worth recalling that Arbus was one of three photographers chosen for the exhibition - Lee Friedlander and Gary Winogrand were the others - and while all three had very distinct visual styles, they were each reshaping the documentary form to pursue a more intimate and personal approach to America's troubled social landscape. All three made use of strange juxtapositions to create a new visual understanding of the commonplace and the exhibition effectively anointed them as the leading photographers of their generation, seeing their work transition from magazine page to museum wall.

At that time, there was virtually no art market for photography and magazine commissions provided an important means of earning a living, getting work published and establishing a reputation. Although celebrated photographers like Walker Evans (1938) and Robert Frank (1958) had been able to publish books of their work, in American Photographs and The Americans respectively, such projects were extremely rare, "galleries dealing in photographic prints were virtually nonexistent, grants were naturally hard to come by, and museums were still adhering to fairly rigid definitions of what constituted photographic art"' (Southall, 1984:153-4). Consequently, commercial assignments existed alongside the more signature projects for which she is known today. Indeed, Arbus began her professional career 
in the 1940s with her then husband, Allan, as partner, in a successful photography business that specialized in fashion and advertising for magazines like Glamour, Seventeen and Vogue, in what today is recalled nostalgically as "the clean commercial style" (Lee, 2003:24), but by 1956 she stopped working on these shoots and began to study with the Austrian photographer Lisette Model, who became a major influence on her work and a professional ally up to her death in 1971.

Model had achieved acclaim initially for her ability to clandestinely capture the foibles of the rich and fashionable on the French Riviera shortly before the outbreak of the second world war and then later in New York demi-monde where jazz musicians, vaudeville performers, cross-dressers and transsexuals feature among her subjects. In both style and content she anticipates territory Arbus would later explore and it is said she acquired from Model's courses both a "hard-boiled audacity" and a "courage to confront extremes in human situations" (Marien, 2010:351). These qualities were further sharpened through her admiration for the notorious tabloid photographer Weegee, and became a leading champion for his work (Crookston, 2005). Photographing New York in the 1930s and 1940s Weegee's world is one reveling in eccentricity, sensation and violence, where the city is "viewed as the site of the unexpected, the surreal and the brutal" (Clarke, 1997:85).

In the literature on Arbus both Model and Weegee are well known influences, but a third photographer is also significant and informed the use of frontal composition in her portraiture. As her most vociferous critic put it: 
What makes Arbus's use of the frontal pose so arresting is that her subjects are often people one would not expect to surrender themselves so amiably and ingenuously for the camera. Thus, in Arbus's photographs, frontality also implies in the most vivid way the subject's cooperation.

(Sontag, 1977:38)

It is evident from her pictures that an interpersonal encounter of some significance has already occurred, so that far "from spying on freaks and pariahs, catching them unawares, the photographer has gotten to know them, reassured them - so that they posed for her as calmly and stiffly as any Victorian notable sat for a studio portrait" (Sontag, 1977:35). Yet in many of her portraits her style is far less formal and bears greater comparison with the techniques pioneered in Germany by August Sander between the world wars. His ambitious attempt to systematically take portraits of every occupational type in Germany, which was to be called People of the Twentieth Century, is a sustained attempt to situate an individual's life within the broader, social context of their time and culture, where every detail in the picture is of significance. Each person he photographed, from "the bricklayer's assistant to the notary to the circus hands to the Nazi soldier, is afforded the same staring, frontal portrait" (Gross, 2012:59). When the Nazis came to power in 1933 they attempted to destroy his work, because the images revealed that many of the German people did not have the facial features associated with the Aryan race. Moreover, the series included unemployed and disabled people - the very groups the Nazis would attempt to eliminate. 
It has been argued that the complexities of the Weimar period are condensed in Sander's archival project, and crucially he constructed his portraits according to social, rather than racial, types that differed from Nazi ideologies (Emerling, 2012:147). Sander's subjects are above all else defined by the "blunt facts of social and class standing" created through a rigid hierarchy of social stratification and status distinction, so that what is often "regarded as Arbus's inventiveness with her subject matter...is in fact a registration of how much she understood and took from Sander's inventory of social types" (Lee, 2003:44). The fine balance between social observation and psychological insight rendered in most of his images is achieved through the careful arrangement of sitters and their surroundings, which was then unique and revealed "the extent to which we show rather than reveal a face in any public context" (Clark, 1997:114, emphasis in original). The photographs are rich with sociological possibility and I now turn to a closer look at some examples of her work.

\section{Social portraits}

By the time Arbus began approaching magazine editors in the late 1950s over possible assignments important changes in American magazine culture were already underway. Many were radically rethinking their editorial and visual content, ushering in a period of innovation and experimentation, "inspired by the need for magazines to establish clear, exciting alternatives to the growing competition of television in the battle for an audience and advertising dollars" (Southall, 1984:155). Much of the commentary on Arbus has concentrated on her portraits of "freaks", but this overlooks the "social panorama" on display across her work, where pictures of 
"celebrities, artists, feminists, the wealthy, the middle class, the old, and the young" all appear, but the seeming "lack of an organizational hierarchy" means that "the transvestite in her seedy bedroom is captured in the same square format as the socialite in her ornate bourdoir" (Gross, 2012:17). Operating somewhere between controlled studio portraiture and the spontaneity of street photography her pictures are always interested in artifices and social appearances:

The camera she had chosen, her later use of flash, and her deliberate compositions resembled the techniques of the studio photographer. Unlike the studio photographer, however, she did not invite her subjects to come to her: she went to them, to their neighborhoods, front yards, homes, hotel rooms. For the most part, her portraits were not simply about faces and their expressions. They were also about bodies, clothing, furniture, wallpaper - all the details and appurtenances of an individual's identity. The merging of these disparate techniques seemed truly revolutionary at the time. (Southall 1984:159)

Many have suggested Arbus was especially interested in displaying the inner life of her subjects and their existential condition, but few have attempted to understand how this is achieved in any systematic way.

One crucial exception is Nigel Warburton's (1992) brief but perceptive discussion of how Goffman's (1959) dramaturgical sociology can shed fresh light on Arbus's work. Among Goffman's key insights is the idea that the self is a social product, where human encounters are filled with the arts of "impression management" and avoiding 
the unpleasantness of "discrepant roles." Although his Presentation of Self in Everyday Life (1959/1969) is often criticized for offering "the view that we are all cynical actors performing instrumentally for personal gain" (Manning1992:8), Goffman's argument is a much more subtle and dynamic account of symbolic interaction than such a characterization allows. A significant section of Presentation is entitled "Reality and contrivance" and in it he takes time to set out a position explicitly against the idea that dramaturgical performances are intrinsically false, insincere, dishonest and manipulative. Rather, "we all act better than we know" because our daily conduct derives not from a script, but from "a command of an idiom, a command that is exercised from moment to moment with little calculation or forethought" (Goffman, 1959/1969:80). Here Goffman is emphasizing that the presentation of self always involves an enacted performance, whether we are aware of it or not, and realized in social situations that are subject to normative controls.

Goffman moves beyond hackneyed notions of "putting on act" or "all the world's a stage" by stressing the importance played by the audiences to whom the performance is addressed, and that all "front-stage" performances require a "backstage" (Burns, 1992:112). This dichotomy is introduced at the outset, where he explains that the "expressiveness of the individual (and therefore his capacity to give impressions) appears to involve two radically different kinds of sign activity: the expression he gives, and the expression that he gives off' (Goffman, 1959:14, emphasis in original). Arbus was highly attuned to this distinction between the information an actor deliberately intends and that which is inadvertently achieved in the performance. As she wrote, in words transcribed from a lecture and later 
published posthumously in the introduction of the monograph ${ }^{2}$ that remains the classic collection of her photography:

Everybody has that thing where they need to look one way but they come out looking another way and that's what people observe... Our whole guise is like giving a sign to the world to think of us in a certain way but there's a point between what you want people to know about you and what you can't help people knowing about you. And that has to do with what l've always called the gap between intention and effect...Something is ironic in the world and it has to do with the fact that what you intend never comes out like you intend it. (Arbus et al, 1972:1-2)

The discrepancies between intention and effect, or what Goffman terms the disjuncture between the impressions we continually 'give' and those we actually 'give off' to audiences, are at the core of her work and the next section examines how this juxtaposition animates her compositions.

\section{Between intention and effect}

Among her most memorable images is "Retired man and his wife at home in a nudist camp, N.J. 1963" (in Arbus et al, 2003: 253), taken as part of her unpublished series on "Notes on the Nudist Camp", a draft of her article was later published in Magazine Work (in Arbus et al, 1984:68-9). Both the image and her accompanying text transform a scene of domestic harmony into a humorous debunking of the entire 
naturist enterprise. In the photograph a smiling, middle aged couple sit either side of a television set in a living room bathed in sunlight, both are completely naked except for the man is wearing slippers and the woman wears flip-flops. They appear to be completely at ease with the situation, and it is this image that Warburton (1992) analyses through Goffman's dramaturgical approach. Initially he concentrates on their "intentionally presented selves," noting how the man's whole demeanor conveys the impression he wants to give, that is of someone communicating a complete lack of "shame about being seen to be naked" (Warburton, 1992:402-3). Or as another commentator has put it, the husband "seems quite comfortable to have his small, cigar-butt-shaped penis peeping jauntily from underneath his paunch" (Gross, 2012:83) and is meant to suggest the normality of the setting. Although the woman is less relaxed she cooperates with the desired definition of the situation, which is one of warm hospitality toward a stranger in their parlor ${ }^{3}$, where all the visual props of suburban domesticity are readily identified: net curtains, coffee tables, family photographs on top of the TV set, soft furnishings and so on.

Of course, the humour in the scene derives from how these banal details play off against the overall absurdity of the situation. The disjuncture between intention and effect is readily seen in the woman's more awkward posture that strikes a discordant tone. As Warburton (1992:403) puts it, her "eyes cannot quite return the stare of the lens," while her "feet are placed awkwardly, her knees are close together, and her hands clasped protectively between her legs" works against the relaxed ease the couple are striving to project. On his closer analysis of the setting, the props also subtly undermine the performance - why would an uninhibited couple in a nudist colony require net curtains? The kitsch art hanging over the man's head is of a nude 
pinup girl, the framed family snapshots appear to be of themselves, in full frontal naked poses, so that each detail adds further comic layers to the narrative unfolding in the picture. Warburton's Goffmanesque approach can be applied to any number of Arbus images. In what follows I will extend it to an analysis of two images that were initially published in the Sunday Times Magazine in 1968 under the headline "Two American Families" (in Arbus et al, 1984:106-7), before deepening the approach through a closer look at Goffman's sociology through an Arbus lens.

The first and smaller picture of the two, as it is reproduced in the magazine feature, is entitled A young Brooklyn family going for a Sunday outing, N.Y.C. 1966 and features a young working-class couple with two of their three children. Here the uneasy disjuncture is between how the parents strive to look like glamorous film stars, the young mother unsuccessfully attempts Elizabeth Taylor, while her husband reaches for James Dean, and their sadder realities. Their son stands between them, body contorted and mouth agape, prompting Arbus (in Arbus et al, 1984:106-7) to write he "is mentally retarded, and the family is undeniably close in a painful, heartrending way." The picture is paired with a much larger photograph of $A$ family on their lawn one Sunday in Westchester, N.Y. 1968 and is one of her iconic images. It is a picture of "normals," an affluent American family relaxing in their huge back garden. The father and mother sunbathe on lounge chairs in the foreground, while a child plays alone staring into a circular bathing pool.

It is a complex image and Arbus (in Arbus et al, 1984:106-7) herself states, "I think it's such an odd photograph, nearly Pinter like, but not quite...the parents seem to be dreaming the child and the child seems to be inventing them." .As such the effect 
given off in the picture is a much bleaker and more troubled portrait of family life than that presented by the "Brooklyn family." Every detail in it suggests isolation and distance. The man is tense, his head leans to the side away from his wife, his left hand shielding his gaze as if locked in private thought. The mother is also resting, eyes shut and self-absorbed, wearing make-up and a bikini ${ }^{4}$. A table divides the loungers, and their physical separation is made even more obvious in The Sunday Times Magazine layout, where the seam of the magazine further splits the image, visibly adding to the distance between them. It has been noted that the "setting is stylized... like a stage set" and in Arthur Lubow's reading (2016:426) the "three characters play out their drama as the points of an Oedipal triangle: a sexually provocative mother, a potent, angry father, and at the apex, their young son in his abstracted universe". The setting is crucial to the composition. Almost two-thirds of the picture is taken up with the well-manicured lawn, while the looming presence of tall trees at the back of the garden further heighten the ominous atmosphere. Items of play and pleasure are pushed to the borders, discarded and ignored. All the props echoing the family's aloof detachment from one another. An image of domestic tranquility becomes a "study of estrangement and loneliness which, in its compulsive effect, speaks about a whole culture's condition" (Clarke, 1997:32).

This scrutinizing of specific details to reveal something more general about the human condition is very much the hallmark of Goffman's sociology and it can be extended to his classic work of visual analysis in Gender Advertisements (Goffman, 1979). Much of the book reproduces a large number of commercial advertisements and uses them as visual data. As the title suggests the book addresses how gender 
relations are displayed in them and he explains they work by exploiting a specific set of social conventions:

The magical ability of the advertiser to use a few models and props to evoke a life-like scene of his [sic] own choosing is not primarily due to the art and technology of commercial photography; it is due primarily to those institutionalized arrangements in social life which allow strangers to glimpse the lives of persons they pass, and to the readiness of all of us to switch at any moment from dealing with the real world to participating in make-believe ones. (Goffman, 1979:23)

The analysis develops his previous work deploying dramaturgical metaphors to examine social interaction and he suggests that advertisements can be productively compared to stage scenes, where the ritual displays in them tell us much about gendered social relations in society at large. The book is organised to indicate the various ways gender inequalities are enacted through the sheer attention to detail. The section on the "ritualization of subordination," for example, has an account of how "Women frequently, men very infrequently, are posed in a display of the 'bashful knee bend'" (Goffman, 1979:45) and the accompanying array of visual evidence featuring this form of deferent gesture gives a social scientific understanding of how gender differences are expressed. It provides both a nuanced study of the gender politics displayed in print advertisements and an exploration of the interaction rituals governing conduct in everyday life. 
He was not especially concerned with the commercial aspects of the images, but rather he examined the varying degrees to which photographs can and cannot be regarded as capturing some "real" state of affairs, distinguishing between those intended for "public" or "private" viewing, and those which are "caught" in "candid" moments as opposed to those which are "arranged" or "rigged" in some "covertly contrived" ways (Goffman, 1979:14). Of course, Arbus's work spans these categories, but the key dynamic she shares with Goffman is the understanding of ritual and how it is a placement mechanism affirming the legitimacy (or otherwise) of our positioning in the social structure. Moreover, in all her photographs selfpresentation is always "flawed" in the sense that it always represents a shortfall of agency, a discrepancy between the efforts made to create a self and the failure of those efforts" (Nelson, 2017:137-8). A sustained theme running through Goffman's sociology are the procedures people use to deal with the loss of a social role, such as in his very early paper On Cooling the Mark Out (1952), which foreshadows ideas pursued across his writing. The title is taken from the language of confidence tricksters, where the "mark" is their victim, and "cooling out" describing the techniques sometimes necessary to calm the mark down having just conned the victim in order to reduce the risk of their informing the police. These arguments are developed in much of his writing where he explores the links between pretension and embarrassment, and the damage limitation procedures adopted across society so that role transformations of various kinds, are handled in ways that keep the show running. Not least, since we "are all potential marks, and therefore all liable, some time, to need cooling out" (Burns, 1992:14). Consequently, Goffman thought it was vital to not only study the impressions people give deliberately, but also they give off 
unintentionally. And it is this tension that Arbus explores throughout her work, revealing the masks we try to wear and how they slip in our presentations of self.

\section{Normal appearances}

"Normal Appearances" is the final essay of Relations in Public and can be regarded as a distillation of Goffman's (1971) various explorations of social interaction he had been pursuing over much of his career, but the title also gets to the heart of Arbus's project - how her photographs evoke that troubling void between our inner selfperception and our outer public realities. The "pathos" that arises is "not that of her subjects but that of the viewer", for her "pictures are not about types of freaks but a cataloging of that communal secret of wanting to be 'normal' and wanting to be accepted for who we are" (Hirsch, 2017:414). Violations of the self are a central theme in Goffman's work and running through it are elaborate accounts of normalisation as a powerful form of social control. If The Presentation of Self in Everyday Life (Goffman, 1959/1969) is concerned with the interactional dynamics of supposedly normal people in routine situations, then Stigma (Goffman, 1963b) concentrates on the interactional management of abnormal, discrediting and disfiguring characteristics of spoiled identities. Throughout his discussion of the normal and the stigmatized Goffman emphasises they are interactional roles, and the problem of "passing" in social situations lies at the core of Relations in Public (1971).

The normality and naturalness we find in everyday encounters always have to be contrived and he argues that while "normal appearances", "typical appearances", 
and "proper appearances" are usually pretty much the same, "this agreement conceals the adaptive social processes that produced it and the inevitable possibility that the three appearances will not coincide" (Goffman, 1971:284). There is a strong Durkheimian focus here, on normative regulation and ritual codes, but there is no sense that doing the socially proper thing is actually the right thing to do. Reading Goffman through an Arbus lens opens up this fundamental point to broader scrutiny and adds considerable nuance to what Manning (1992:44, emphasis in original) has termed "the two selves thesis" in Goffman, where the individual is regarded "as a set of performance masks hiding a manipulative and cynical self". Arbus's images unsettle this metaphor of theatre and confidence trick by revealing just how much information is given off inadvertently, raising important questions over the extent to which the performer is aware of the performance and her "work taken as a whole tells a story about agency and its limitations" (Nelson, 2017:135). Even though Goffman (1959/1969:244-5) initially maintained the individual can be divided "two basic parts" and insisted that the self is "a performed character...a dramatic effect arising diffusely from a scene that is presented' (Goffman, 1959/1969:245) he later characterizes the human self (again following Durkheim) in terms of a 'kind of sacredness that is displayed and confirmed by symbolic acts" (Goffman, 1967:47).

In his extensive analyses of deference and demeanour Goffman demonstrates the binding ties the rules governing interaction produce, maintaining how "in many social encounters, individuals are in fact concerned with a ritual celebration of the individual and simultaneously with protection of this vulnerable self by way of interaction rituals" (Jacobsen and Kristiansen, 2015:115). The best illustration of this Durkheimian understanding of the sacredness of the human self, but applied in a 
modern secular setting, is Goffman's memorable account of "civil inattention", which he uses to describe the delicate, mutual courtesies strangers display on busy city streets or in confined spaces (such as elevators). As he put it:

What seems to be involved is that one gives to another enough visual notice to demonstrate that one appreciates that the other is present (and that one admits openly to having seen him), while at the next moment withdrawing one's attention from him so as to express that he does not constitute a target of special curiosity or design.

(Goffman, 1963a:84)

Goffman coins the term "body idiom" to describe the shared conventions enabling us to make sense of one another through clothing, comportment, physical gestures, facial expressions and the like, which he distinguishes from the more well-known notion of body language. The information communicated in this way lacks the symbolic complexity of spoken or written language. Yet the significance of nonverbal communication in any social encounter is that it never ceases, for while "an individual can stop talking, he cannot stop communicating through body idiom; he must say either the right thing or the wrong thing. He cannot say nothing" (Goffman, 1963a:35). The Arbus images discussed in this paper, and her work more generally, shed compelling light on such "situational proprieties" and how such rules obliging us to "fit in" can also be circumvented or defied (Goffman, 1963a:42).

It has been said of her photography that no 'matter how incongruous or awry an appearance may be at first glance, Arbus's portrait treatment often conveys the 
integrity and self-possession of an individual' (Goodwin, 2009:157). This is an important point, for Goffman has been criticised for painting too bleak and unpleasant a picture of social interaction, where "sincerity becomes secondary to manipulation and appearances" (Stein, 1991:426). A view famously put by Alvin Gouldner (1970) where he denounces Goffman's sociology as symptomatic of the crisis of the discipline in the 1960s, which he suggests is one really speaking to the new, college-educated middle class, aware of the irrationalities of modern life, but anxious to benefit from them through cynically "playing the system". It is "a social 'dramaturgy' in which appearances and not underlying essences are exalted" (Gouldner, 1970:378). As he puts it:

"Pop art" declares an end to the distinction between fine art and advertising, in much the same manner that dramaturgy obliterates the distinction between "real life" and the theater. The "Mafia" become businessmen; the police are sometimes difficult to distinguish from the rioters except by their uniforms; heterosexuality and homosexuality come to be viewed by some as akin to the difference between righthandedness and lefthandedness; the television program becomes the definition of reality. The antihero becomes the hero. Once established hierarchies of value and worth are shaken, and the sacred and profane are now mingled in grotesque juxtapositions. The new middle class seeks to cope with the attenuation of its conventional standards of utility and morality by retreating from both and by seeking to fix its perspective in aesthetic standards, in the appearances of things. 
This is a lengthy passage, but what it manages to convey is the distinctive, deadpan sensibility that flourished in the 1960s and which he locates in Goffman. Indeed, he had earlier denounced the sociology of deviance as "glib", for while it might be at ease in the "cool worlds" of drug addicts, jazz musicians and mental health patients (amongst other "outsiders") it amounted to little more than a "titillated attraction to the underdog's exotic difference" (Gouldner, 1968/1973:37-8). This critique proved to be influential, but it is worth noting that Goffman (1963b:167) himself was highly suspicious of the entire field and aware of the many contradictions in it, considering deviance a category created by sociologists mainly to give sociologists things to study.

It is also striking just how much of Gouldner's combative reading of Goffman recalls Sontag's (1977:45) bitter assessment of Arbus, where "both freaks and Middle America were equally exotic" across her work. If anything Arbus draws our attention to how these conventional distinctions are constituted, and Goffman is emphasising the unavoidably performative character of social life. In both the notion of self is a fragile construction, but this does not imply a rejection of a possible inner authenticity. Instead they both share a concern with how we manage discrediting information about ourselves and the kind of conventions that sustain trust among strangers in modern, urban environments. This is not to suggest that people are inevitably manipulative actors or strategic game players - rather Arbus's photography and Goffman's sociology explores the tensions between appearance and reality. From the outset Goffman maintained a contrast between the tactical and 
the tactful, so that we not only take others into consideration but we show respectful consideration for others. This emphasis on ritual has its origins in Durkheim, who insisted that rituals build integrity and social solidarity among participants, yet Goffman's innovation was to render it "relevant to the analysis of gatherings" by demonstrating how "ritual is not simply about expressions of warm regard for the person", but is a "variable property of social interaction" (Smith, 2006:50-1). Arbus's method of making the familiar strange powerfully confronts our assumptions about the taken-for-granted nature of everyday life, while her ability to reveal the familiar within the extraordinary enlarges our understanding of ourselves and the interactional dynamics of excluded status.

\section{Conclusion}

In offering a consideration of Arbus and Goffman my aim has been to move "toward a more sensual integration of method, subject, and situation" and remind us of a visual heritage "that is today all too often forgotten amidst the welter of surveys, statistical analysis, and big data" (Ferrell, 2017:51). They both draw attention to the logic of sameness and difference, unsettling the terrain of social identity. By reminding us that photographers' preoccupations with outsiders, the abnormal, marginal and outcast has important parallels with how sociologists have sought to understand such conditions the suggestion is that their images provide rich resources for enlivening sociological concerns. In particular, one familiar complaint levelled against Goffman is the unduly episodic, fragmentary character of his scholarship - starting each book as if it were the first, rarely consolidating ideas or 
looking back and juggling concepts without building connections between them (Lofland, 1980). After his death in 1982 there have been attempts to order these meandering insights into a more coherent whole, something merely hinted at during his lifetime. By considering his sociology in tandem with Arbus's photography we gain deeper understanding of how even the most private aspects of our lives are socially organised through interaction rituals and the powerful sense impressions they generate. Their respective projects take us closer to "the essentials of human conduct, and it is this crucial starting point that we as sociologists have simply overlooked or taken for granted for far too long" (Chriss, 1995:8). Although these words were written over twenty years ago, in a review essay largely devoted to Manning's (1992) attempt to systematize Goffman's microsociology, they remain a vital reminder of the fundamental questions the work continues to provoke and the rich resource it provides for the social sciences more generally.

\section{Acknowledgements}

I would like to thank the two anonymous reviewers for their helpful comments on a previous version of this paper, as well as Carolina Cambre who offered constructive suggestions on an early draft, and to the editors for their assistance throughout the process.

\section{Funding}

This work was supported by a Leverhulme Trust Major Research Fellowship, MRF2014-052.

\section{References}


Adler, PA and Adler P (2003) Constructions of Deviance: Social Power, Context, and Interaction. Belmont, CA: Wadsworth.

Arbus D et al (eds) (1972) Diane Arbus, New York: Aperture.

Arbus D et al (eds) (1984) Diane Arbus: Magazine Work. New York: Aperture.

Arbus D et al (eds) (2003) Diane Arbus: Revelations. New York: Random.

Bosworth P (1984) Diane Arbus: A Biography. New York: Alfred A. Knopf.

Burns T (1992) Erving Goffman London: Routledge.

Carrabine, E. (2017) Crime and Social Theory Basingstoke: Palgrave MacMillan.

Chaplin, E. (1994) Sociology and Visual Representation, London: Routledge.

Chriss, J. (1995) 'Some Thoughts on Recent Efforts to Further Systematize

Goffman, in Sociology \& Criminology Faculty Publications. 99.

http://engagedscholarship.csuohio.edu/clsoc_crim_facpub/99

Clarke G (1997) The Photograph. Oxford: Oxford University Press.

Crookston, P. (2005) ‘Extra ordinary’, in The Guardian, 1 Oct 2005.

https://www.theguardian.com/artanddesign/2005/oct/01/photography

Emerling J (2012) Photography: History and Theory. London: Routledge.

Evans W (1938) American Photographs. New York: MoMA.

Ferrell J (2017) "We never, never talked about photography": Documentary

photography, visual criminology, and method. In: Carrabine E and Brown M (eds)

Routledge International Handbook of Criminology. London: Routledge, pp. 40-52,

Frank R (1958) The Americans. Göttingen: Steidl.

Goffman E (1952) On cooling the mark out: Some aspects of adaptation to failure. Psychiatry 15(4): 451-463.

Goffman E (1953) Communication Conduct in an Island Community. Unpublished doctoral dissertation. Department of Sociology, University of Chicago. 
Goffman E (1959/1969) The Presentation of Self in Everyday Life. Harmondsworth: Penguin.

Goffman E (1961) Asylums. Harmondsworth: Penguin.

Goffman, E. (1963a) Behavior in Public Places: Notes on the Social Organization of Gatherings, New York: Free press.

Goffman E (1963b) Stigma. London: Penguin.

Goffman E (1967) Interaction Ritual. Harmondsworth: Penguin.

Goffman, E. (1971) Relations in Public: Microstudies of the Public Order, Harmondsworth: Penguin.

Goffman E (1979) Gender Advertisements. London: MacMillan.

Goodwin A (2009) Modern American Grotesque. Ohio: Ohio State University Press. Gouldner, A. (1968/1973) 'The Sociologist as Partisan: Sociology and the Welfare State', in For Sociology, London: Allen Lane.

Gouldner, A. (1970) The Coming Crisis of Western Sociology, New York: Basic Books.

Gross F (2012) Diane Arbus's 1960s: Auguries of Experience. Minneapolis: University of Minnesota Press.

Hackett S (2016) Social subjects. In: Hackett S and Shedden J (eds) Outsiders: American Photography and Film 1950s-1980s. Toronto: Art Gallery of Ontario, pp.915.

Hirsch, R. (2017) Seizing the Light: A Social \& Aesthetic History of Photography, London: Routledge.

Holliday R (2000) We've been framed: visualising methodology. Sociological Review 48(4): 503-521. 
Jacobsen, M. H. and S. Kristiansen (2015) The Social Thought of Erving Goffman, London: SAGE.

Lee AW (2003) Noah's ark, Arbus's album. In: Lee AW and Pultz J (eds.) Diane Arbus: Family Albums New Haven, CT: Yale University Press, pp.21-62.

Liazos A (1972) The poverty of the sociology of deviance: Nuts, sluts and preverts. Social Problems 20(1): 103-20.

Lofland, J. (1980) 'Early Goffman: Style, Structure, Substance, Soul', in Ditton, J. (ed.) The View from Goffman, London: Macmillan.

Lubow, A. (2016) Diane Arbus: Portrait of a Photographer, New York: Harper Collins. Manning P (1992) Erving Goffman and Modern Sociology. Cambridge: Polity. Marien M (2010) Photography: A Cultural History, London: Laurence King. Nelson D (2017) Tough Enough. Chicago: University of Chicago Press.

Rose G (2014) On the relation between "visual research methods" and contemporary visual culture. The Sociological Review 62(1): 24-46.

Simmel G (1908/1921). Sociology of the senses: Visual interaction. In: Park, RE and Burgess EW (eds), Introduction to the Science of Sociology, Chicago: University of Chicago Press, pp.356-361.

Sontag S (1977) On Photography. London: Penguin.

Southall T (1984) The magazine years, 1960-1971. In: Arbus D and Israel M (eds) (1984) Diane Arbus: Magazine Work. New York: Aperture, pp.152-171.

Stein, M. (1991) 'Sociology and the Prosaic', in Sociological Inquiry 61(4):421-433. Warburton N (1992) Diane Arbus and Erving Goffman: The presentation of self. History of Photography 16(4): 401-404 


\section{Notes}

${ }^{1}$ The project proposal from 1963 is included in the book Diane Arbus: Revelations (Arbus et al, 2003), which was published posthumously and the collection gives a sense of the breadth of her vision. At the around the same time as the Guggenheim project was conceived Goffman (1967:2-3) was advocating a 'sociology of occasions' in the essays collected in his studies of interaction rituals, that was not so much interested in 'men and their moments. Rather moments and their men.'

${ }^{2}$ The Diane Arbus monograph was published the year after her death to coincide with a oneperson retrospective show of her work at MoMA, edited and designed by her daughter Doon Arbus in collaboration with Marvin Israel. The fifteen pages of Arbus's words are collected from several sources that appear before the photographs. Those familiar with the subsequent literature on Arbus will recognize that much of it is published without the benefits of reproducing her most famous images. All of this is the result of restrictions the Arbus Estate places on her work. It routinely refuses permission to reproduce her photographs and this has hampered scholarship on them, where appropriate I have referred the reader to the handful of publications where the photograph discussed in the text can be found. I should acknowledge that the Estate were prepared to grant permission to reproduce the images in this paper, but only in the print version, which was unacceptable to the publisher (who wanted to publish them in the online version as well).

${ }^{3}$ Arbus was also a participant observer and went nudist for a week during the shoot on the camp. Her notes begin by gently describing the mystery of the place, where everyone is pleasant and polite, engaging in routine suburban pastimes through to a pointed denunciation of the absurd utopianism in the subculture. She concludes: 'Sometimes you begin to wonder. There is an empty pop bottle or a rusty bobby pin underfoot, the lake bottom oozes mud in a particularly nasty way, the negroes are not there, most people don't look so good, some guy asks, "What kind of bees give milk?" and answers, "boobies," the outhouse smells, the woods look mangy. It is as if way back in the Garden of Eden, after the Fall, Adam and Eve had begged the Lord to forgive them; and God, in his boundless exasperation, had said, "All right, then. STAY. Stay in the Garden of Eden. Get civilized. Procreate. Muck it up." And they did.' (in Arbus et al, 1984:69).

${ }^{4}$ In correspondence with her editor at the Sunday Times Magazine Arbus writes that what initially attracted her to the wife was how: "there is a woman I stopped in a Bookstore who lives in Westchester which is Upper Suburbia...She is about 35 with terribly blond hair and enormously eyelashed and miniskirted like a former showgirl and booted and probably married to a dress manufacturer or restauranteur and I said I wanted to photograph her with husband and children so she suggested I wait till the warm weather so I can do it around the pool!... They are a fascinating family. I think all families are creepy in a way" (in Lubow, 2016: 423). According to her critics Arbus clinically and cynically exploited her subjects, and there is much in this passage speaking to her working methods, yet they also reveal a great deal of her overall project - that is a dismantling of artifice and subverting the comfortable assumptions of white, middle-class normalcy. 